\title{
Toward Meaningful Dialogue
}

Rice's faculty, administration, and students often seem to be working at crosspurposes. The struggle is particularly evident when students are not involved in decision-making in any capacity other than to obey, and as a result can air their suggestions only as criticism after the fact-criticism which must be all the louder and all the stronger because it is so seldom and so dimly heard.

The discord belies an important fact, however: that Rice students, faculty and administrators all are motivated by the desire for excellence. All pursue excellence for Rice.

The creation of the Undergraduate $\mathrm{Af}_{-}$ fairs Committee last summer was a significant step toward co-operation. A student-faculty-administration committee was created which had real powers and responsibilities. The group which judges and recommends changes in University policy represents students as well as administrators. In the debate over policy, both views can be heard. Dialogue occurs.

Real communication is an elusive thing. Merely placing students and administrators in the same room for a period of time, or allowing them to write letters to each other, achieves nothing. But in a committee which must reach a decision, which must achieve a compromise, which must therefore heed the varying viewpoints and aims of its members, real communication must take place. Apparently it does.

The value of this dialogue is great. It allows the voice of students to be heard. Their resources, their ideas, their contributions to the future excellence of the University are thus utilized. Reciprocally, dialogue also opens the ears of the students, and very often their supportive resources for proposed policies can be obtained by enlisting their aid in drawing them up.

This communication between faculty, students and administration leads to a sympathetic understanding of each by each; co-operation is facilitated.

Perhaps insurmountable human factors preclude perfect communication, but organizational obstacles prevent it now. The organizational obstacles can be removed. The proposal made by Student Association President Bill Broyles to the Student Senate Tuesday night would begin to remove them. Adding student representatives to these nine University committees would add student voices in places where decisions must be made.

Some of these committees are faculty committees rather than administration committees; some are administrative rather than policy-making. But student resources, student ideas and co-operation, would be of value in each of these areas. Student members added to the committees could in no way dominate the committees, but they would permit communication and dialogue.
As the college system develops, and University policy is clarified, we are hopefully approaching a definition of the student's role in the University. Students exist in symboisis with other interests in the University; whereas administration and faculty are interested in achieving excellence in the education offered, we are interested that excellent education is offered. Surely students, faculty and administration exist as some sort of partnership, which will function best when the partners co-operate and communicate with each other.

Faculty and administrators must realize that students have valuable contributions for the future of the University; their ideas and perspectives are significant. Their co-operation in the pursuit of excellence is vital. The resource and opportunity should not be wasted.

SANDY COYNER

\section{Financial Pra}

Behold! Students no longer need fear only academic probation from grades or disciplinary probation from hostile deans or special probation from various judicial bodies around campus.

The Cashier's Office, that impartial arbiter of any dispute between supply and demand, has evolved a new kind of punishment-one that best be termed financial probation.

The notice that you are on financial probation - a notice which no small number of students received this week-takes the form of a financial statement which lists the amount owed to the University for various items ranging from course changes to two semesters worth of room and board. It says at the bottom of the statement, "The above items are now due. Please be advised that you will not be issued any certificate of attendance or transcript of credit until your account is paid."

\section{The Grawy Train}

The Student Senate has fairly liberal funds budgeted for Rice delegates to various conventions, symposia, and conferences around the state and country. Any student is eligible to represent Rice at most of these gatherings.

There are two things wrong with the delegate situation at present. First, many opportunities go begging: nobody wants to attend. Second, many of those who do attend make a superficial report of the proceedings at their conference.

We do not think the Student Senate should discontinue its support of these conferences. Rice has much to offer them and gain from them. But the Senate should set to work to encourage a more active participation in and reporting of the conferences to which it sponsors delegates. 